\title{
Exploration and Practice of the Organic Integration Mode of Ideological and Political Education and College English Teaching in the New Era
}

\begin{abstract}
Yunhui Li
Fuzhou Preschool Education College, Jiangxi, Fuzhou,344000

278835001@qq.com

ABSTRACT

we must clearly understand that we should always regard moral education as the fundamental task, adhere to the party's educational policy, and focus on the fundamental issues of what kind of people to cultivate, how to cultivate people, and for whom to cultivate people. English course is similar to ideological and political course. English has many characteristics such as humanism, speculation and instrumentality, which are in line with ideological and political course. The core of this paper is to "integrate ideological and political courses with all aspects of College English Teaching", and is committed to cultivating qualified, noble and honest students, so as to let the principle of living in the world penetrate into the whole process of undergraduate English teaching. In the Symposium of school ideological and political teachers, general secretary Xi Jinping took the overall development of the party and the state as the starting point, and emphasized the importance of carrying out ideological and political theory courses. The only way to realize the party's fundamental mission is to cultivate people who are capable of succeeding and prospering, and how to cultivate people who are able to succeed and accomplish the party's great cause and prosperity. Therefore, every aspect should focus on in-depth exploration of Ideological and political theory course.
\end{abstract}

Keywords: new era, ideological and political education, English teaching, organic integration, mode

\section{新时代思想政治教育与高校英语教学有机融合模式的 探索和实践}

李云辉

抚州幼儿师范高等专科学校 江西 抚州 344000

278835001@qq.com

摘要

在高校进行教育的过程中, 我们务必要清晰地了解, 将立德树人作为教育的根本任务, 同时, 要坚持贯彻党的 教育方针, 重点完成培养什么样的人、如何培养人、为了谁去培养人的根本性问题的工资。高校教育中，英语 课与思政课同工异曲，英语所拥有的人文性、思辨性和工具性等特点，与思政课有许多的符合点。本文中，通 过叙述 “将思政课和高校英语教学各环节相融合”, 使之帮助高校培育具备合格、高尚、耿直品格的学生, 让 立身处世的原则渗透到本科英语教学的全过程之中去。

关键词：新时代；思想政治教育；英语教学；有机融合；模式 


\section{1. 序言}

在高校思政课教师座谈会中, 习近平总书记把党 和国家事业发展的全局作为出发点, 着重强调了开展 思想政治理论课的重要性。唯有始终牢记立德树人的 根本性任务, 坚持贯彻党的教育方针, 重点完成培养 什么样的人、如何培养人、为了谁去培养人的根本性 的问题，方能实现党和国家事业的繁荣昌盛、后继有 人，有利于成就伟大事业、完成伟大梦想。所以，每 个方面都应该着重深入对于思想政治理论课的探索。

\section{2. 英语课堂与高校思政课相融合的作用与 意义}

将与习近平主席所批属的关于高校教育改革文 件的指导精神, 教育部门的指导建议与高校自身的发 展特点相结合, 高校自开设以来就本着 “教书育人” 的原则, 对教学形式与教学内容进行探索与革新。除 此之外, 社会媒体对于高校的改革也是高度重视的, 积极报道高校的思政课教育的必要性与急迫性; 因此 结合高校自身发展需求, 各高校可以使用小组探讨、 学习等方式进行课堂开展形式的多样化; 并且从各个 领域上教育工作者、不同学院的学生与思政课相结合 进行研究。虽然高校在以上方面的革新热火朝天, 但 是将英语教学与思政课相结合方面的变化还是较弱。

各高校实行英语教育都具有自身的特别性。第一、 随着全球化的变化, 英语是国际的通用语言。所以高 校将英语教学作为基础类课程进行教学, 并且结合教 学特点可知: 英语教学内容丰富、时间长、教师与学 生之间的互动性高等特征; 并且英语教学教师与学生 互动频率高使学生会受教师影响较深。第二、英语教 学具有通用性、辩证性等特点, 并且与思政课具有不 谋而合之处。第三、从英语教学的教材角度上来看, 由于教材大多为国外引进, 其中所撰写的角度和观点 会不同, 所以教师应该认真进行备课, 进行客观的讲 解, 从这可以看出, 高校英语是一种思想文化的摩擦 与交流, 对于中外文化的不同领域进行比较, 最后将 思政课结合英语教学的特征融入其中。

\section{3. 将思政课与英语教学相融合的途径}

\section{1. 将思政内容与英语教材相结合。}

在英语教材中含有许多良好的篇章以图文结合 的方法讲述了全球各地的生活习俗与文化观念等内 容, 这种知识与文化相结合的方式就是思政教育与英 语教学相结合的表现方式。并且教材的课后练习中也 含有文化的差异的比较, 教师可以结合教材内容, 将 思政教育内容与教材相融合, 进行默转潜移的影响, 推动学生对世界文化差异的正确理解, 做到 “取其精 华、弃其糟粕”, 不断弘扬中华民族的优秀传统文化。

\section{2. 在思政课堂中加强师生交流}

随着教育的不断变革, 学校越来越重视思想政治 的教育。在学校进行思政教育的过程中, 老师和学生 之间的交流是十分重要的。比如在英语课堂上, 英语 老师在教授学生课本知识的基础上, 还应该关注学生 在生活和学习中发生的事情, 加强和学生的交流, 在 学习和生活中引导学生健康发展, 及时发现和解决学 生们的问题, 这样可以增强老师和学生的感情, 有利 于形成良好、轻松的师生关系。英语老师应对传统的 教学方式进行创新, 在英语课堂上要加强与学生的互 动, 通过提问、辩论等方式让学生都积极的参与到课 堂学习中, 尤其对英语水平不足的学生要更加关注, 对待学生要采取鼓励的态度, 及时发现学生在学习中 的进步, 通过鼓励学生来增强学生的自信心和学习兴 趣。老师通过加强师生交流和鼓励式教学方法营造了 轻松的课堂氛围, 有效解决了学生在生活和学习方面 出现的问题, 同时也促进师生关系的进步, 更加方便 老师对学生进行思想政治教育, 通过正确的教育教学 方式来促进学生全面发展。

\section{4. 如何将英语课程与思政教育有效结合}

为顺应时代发展, 高校越来越重视思政教育的开 展。现在高校已经将思政教育与英语课堂有效结合在 一起, 高校对传统英语教学方式进行创新, 不仅重视 学生英语的学习能力和应用能力, 还更加重视如何将 英语课程与思政教育有效结合在一起。高校要求老师 在学生阅读有关思政文章时, 通过对文章的翻译、解 析来对学生进行思政教育。在学校举办有关思政的英 语活动时, 老师应鼓励学生参加此类活动, 通过参加 英语活动来推动学生在思政方面的进步。在将英语课 程与思政教育有效结合的过程中, 不仅可以提高学生 的英语水平, 还可以使学生在思政方面得到良好的引 导。

\section{1. 高校英语教学方式}

高校进行英语教学的教学渠道分为四个模块, 分 别是: 网络平台、期末考试、听说读写和翻译。老师 运用这四种方式对学生进行英语教学, 通过教授基本 知识理论和考核的方式来提高学生英语水平。这种教 授和考核的方式是当今高校的教学方式。

\section{2. 将思政课与英语教学有效结合的措施}

\subsection{1. 在课堂开始之前}

合理的应用课堂前的时间进行 3 到 5 分钟的演 讲, 这对学生个人的修养与气质会有很大的提升。还 要发挥好读写译和视听说课堂对学生的引导作用, 有 效的引导学生向着时政热点和课堂学习的相关主题 方面进行演讲, 让即兴演讲与有准备的演讲相互融合。 例如: 在新一代高校英语的提高篇章中, 第一单元的 
内容是：数字时代的交流以及关于横跨国家的交谈, 针对这一单元的内容, 教师要求学生结合课文内容在 课堂上与大家分享自己对健康的运动方式、合理运用 电子平台进行网上交友和交流等问题的看法, 通过这 样的分享方式, 可以让学生了解到现实生活中与亲朋 好友面对面的交流是非常有必要的。

另外, 在每次课堂前, 教师还可以要求学生就有 意义的新闻和课文中的相关主题开展演讲, 并要求教 师对人生、理想、职业、婚姻、交友等话题进行引导 和讲解, 让学生在与师生和同学的交流之中形成良好 的认知。

\section{2. 2. 在课堂之上}

（1）教师在讲解课文的时候, 要利用课堂主题 的生动鲜明的特点和时代特色开让学生养成更正确 的人生观、价值观、世界观。在新视野中 《如何应对 地震》 ("How t o P r e p a r e f o r E a r t h q u a k e s ") 一文的授课中, 教师可以从地震 的征兆、起因、危害等问题着手展开讲解, 再从这几 个话题中引出 2008 年的汶川地震, 讲解这次地震的 严重程度, 着重的让学生了解到地震期间我国各方的 支援、军队救援人员的付出以及地震带来的人间温情 与人间关爱等, 再将学生引入对我国的应急机制、我 党对人民生命财产的爱护以及我们制度的优越性等 问题的讨论之中。

（2）让学生了解中外文化的差异, 并对文化进 行对比分析, 以此来提高学生对我国文化的自信程度。 在《新一代高校英语 (发展篇)》关于“社交媒介和友 谊”主题的授课中, 教师要将学生引入友谊话题的讨 论之中, 并将问题的深度延伸至孔子、孟子的哲学思 想、择友交友的方法与原则以及良师益友的重要性等 探讨上, 以此来增强学生的做人做事的水平。在文化 习俗, 风景名胜, 风土人情, 各种美食等相关话题的 内容讲解中, 教师可以采取对我国优良传统节日的了 解的方式来让学生加强对课程内容的理解与掌握, 比 如对春节、七夕、清明等传统节日的了解以及对长城、 山川、江南等风景欣赏。这样的语言交际的方式, 不 仅让学生增加对我国优秀传统文化和大好河山的敬 畏和赞叹, 并让学生在不知不觉中增强文化自信心。

(3) 对比中西两方面对问题时所采取的策略和 态度, 从而激发学生对我国社会主义制度的优越感, 抒发爱国情怀，增强民族自豪感和民族自信。

《新一代高校英语 (发展篇)》有一篇关于中国 发展的一一《中国与世界》, 其中提及到, 虽然中国逐 渐振兴, 屹立于世界之林中, 但也遭受了某些国家的 抗拒, 甚至有些国家提出了 “威胁论”, 这些显然都是 谬论。讲课过程中, 我们会借助理论证明、话题探证 明社会主义制度的正确性, 并且教授学生中国在党的 领导下会逐步辉煌但不是威胁的理论。对于反对 “威 胁论” 最有力的证据是中国及中国人民的责任和担当, 比如 “一带一路 “的提出、护航任务的执行、命运共
同体的建构、无私救助盛行埃博拉病毒的非洲以及对 联合国的大力支持等等。这些无一不展示着中国在国 际上的责任和大国担当, 对提高学生的思想觉悟和责 任担当具有重要意义。

（4）借助网络技术深入学习, 网课和综合测验 可以巩固课堂内容, 在网络教学平台对学生进行分组, 每个小组分有不同的主题, 在课下沟通探讨并制作 ppt 和总结报告, 可以使学生深入研究课题。

\subsection{3. 课下}

学生课下时间充足, 教师要教导学生把课下时间 的作用发挥到最大, 教师可以借助 $Q Q$ 、微信、钉钉 等软件发布一些有关文章、视频和课件引导学生, 但 老师不要发挥太多的作用, 以防主次颠倒。学生课下 要自主进行学习实践, 参加辩论进行演讲, 并且要利 用好第二课堂活动, 像模拟联合国大会等含金量高的 活动。在英语实践中提高学生的英语实际应用素养, 与此同时, 也有利于教师课堂教学的开展。在这种思 政教育的熏陶下, 有益于学生建立起制度自信、文化 自信和道路自信。

\section{5. 结语:}

教学的目标是: 通过教师的教学将思政教育融入 英语中, 达到英语水平提高和思想道德素养的同时提 升, 并且能将英语素养应用到实际中。为达到以上效 果, 教师要始终把培育学生做一个耿直、品德高尚的 人作为制高点, 将为人处世的道理传授给学生。教师 还要不断创新教学模式, 革新教学方法和内容, 注重 线上和线下的结合，细心把握好课上的每一分钟，以 提高学生实践创新能力为主。注重教学反馈, 并及时 调整课程内容和模式。教师更要注重与学生的和睦交 流, 不仅是学生的老师, 也是学生的朋友。此外, 教 师还要重视自身思想政治素质的培养。如此, 方能让 学生达到从知识获取到能力素养提高的转变。

\section{项目基金}

2018 年江西省高等学校教学改革研究课题（重 点课题): 《大学英语写作教学中的 “说作文” 教学模 式研究》

\section{REFERENCES}

[1] Wen Zhonglian" Ideological and political Education and the Promotion of traditional Culture in Foreign language Curriculum under the background of Belt and Road J]. Initiative Journal of Shanghai Institute of Electric Power,2018,(0 s1). 35-38.

[2] Wang Yan, Li Yini, Zhang Jiahan, et al. The Exploration and Practice of the Construction of the Characteristic Ideological and Political System in Foreign Language Colleges - - Taking the 
Major Course of Foreign Language Education as an Example [J]. Youth Development Forum,2017,(3). $40-46$.

[3] Mai Xiaoling. A Brief Analysis of Ideological and Political Education in College English Teaching [J].].1 Journal of Beijing Electric Power College (Social Sciences Edition),2010,27(5):106-107.

[4] Zhong Congling. A Probe into the Path of Infiltrating Ideological and Political Education in College English Teaching [J]. Journal of Qingyuan Vocational and Technical College. 2020,(3). 86-90.

[5] Zou Chaozheng. Humanistic Quality Education and Reform of College Public English Teaching [J].] e Journal of the New Educational Age (Student Edition). 2018,(27). 193.

[6] Sun Rurui. A Approach to Integration of Ideological and Political Education in College Public English Teaching [J].]1 Journal of Jilin Institute of Agricultural Science and Technology. 2019,(2). $100-102$.

[7] Wang Wenxin. A Study on the Importance and Application of Ideological and Political Education in English Teaching J]. Higher Vocational Education Journal of Hubei Open Vocational College. 2020,(1). $90-91$.

[8] Chen Lixia. The Ideological and Political Value Connotation and Realization Path of College English Major Curriculum - - Taking Comprehensive English Curriculum Reform as an example [J]. Journal of Jiangxi University of traditional Chinese Medicine ,2019,(3). 104-107.

[9] du Gangyue, Sun Ruijuan. A Study on the Effective Strategies of "Curriculum Thought and Politics" in College English Teaching [J].] Journal of Yan'an University (Social Sciences Edition),2019,(4). $122-126$.

[10] Wang Zongzhong, Sun Fang, Xue Wenjun, et al. On the Ideological and Political Exploration of the Course of Integrating Medical Humanities into English Teaching —— Taking MedicalStory as an Example Health Vocational Education ,2019,(3). $68-70$.

[11] Wang Jing. An Interpretation of Elements Structure and Characteristics of Ideological and Political Education Resources School Party Building and ideological Education (higher Education Edition),2015,(3). 18-20.

[12] Sasha Wang. A Study on the Strategies of the Organic Integration of Ideological and Political Education and English Classroom Teaching in
Secondary Vocational Schools [J].]; and Journal of Kaifeng Institute of Education,2019,(6). 158-159.

[13] Chen Anqi. An Analysis of the Current Situation of Infiltrating Ideological and Political Education in College English Teaching [J].].1 Contemporary Educational practice and Teaching Research ,2016,(5). 234-235.

[14] Ma Yuhua, Yang Ruihong. Study on the Teaching Mode of Sino-foreign Cooperative School English - - Taking the Sino-Australian Cooperative Project of Yangzhou Vocational and Technical College as an example [J].] Heilongjiang Education (higher Education Research and Evaluation Edition),2011,(8). 89-90.

[15] Li Chao, Liu Aizhen. An Improvement of Chinese Cultural Content in College English Teaching Materials [J].]; and Journal of Chongqing Jiaotong University (Social Sciences Edition)2007,(2). $120-122$ 